\title{
Therapeutic Overzealousness. A Debate on Criteria for Withholding and Withdrawing Life-Sustaining Treatment
}

\begin{abstract}
Greater human longevity is one of the biggest achievements of medicine. Timely medical interventions save countless human lives. But some of them, especially those undertaken in the face of imminent death, often generate serious ethical dilemmas. After reaching a certain critical point, the otherwise welcomed and blessed possibilities of prolonging life sometimes degenerate into a painful prolongation of dying. A spontaneous moral intuition, as well as a more balanced, careful ethical reflection - for which human life constitutes the highest value - permits withdrawal of ineffective therapy. But just what are the criteria for making that crucial decision to terminate a medical therapy? How does one define them? The article opens with the overview of terminology applied to medical interventions that fall into the category of inadequate treatment, both from the perspective of medical futility (futile treatment), the standpoint of the physician (overzealous treatment) and the actual suffering of the patient (burdensome treatment). It then examines the criteria for the termination of treatment, among which the prognosis of imminent death and disagreements over the extent of the basic medical care play crucial roles. The final parts of the article focus on some additional, though by no means less important, issues relating to end of life, like the truth at the sickbed, patient's advance decision concerning the extent of medical interventions he is willing to accept and the physician's conscience clause.
\end{abstract}

\section{Keywords}

Dying, futile treatment, overzealous therapy, basic care, conscience clause, advance decision, truth at the sickbed.

What are the limits of medicine? How long should one keep on trying to overcome an illness, his own or that of others? The debate on the meaning of futility and related operational criteria is still in its infancy; however, its history reaches back to medical antiquity. Even Hippocrates, otherwise known for his 
outstanding respect for human life, cautioned his colleagues against visiting incurably ill patients. ${ }^{1}$ Though, to tell the truth, he advised this more out of fear of compromising their reputation, or being accused of causing their death, than out of concern to spare them painful or uncertain remedies.

Things have changed over the centuries, but the ancient dilemma about 'when to stop' continues to perplex medical practitioners and patients alike perhaps even more than in Hippocrates' times. The rationale, legitimacy and ethical value of the old belief that physicians should employ every available means and do everything they can to save their patients' lives is being seriously questioned. Modern medicine can save and prolong lives but it can also prolong suffering and dying. Medical ethicists, today, pay a lot of attention to the right of the patients to participate in the decision-making processes concerning their treatment.

Before attempting to sort out viable criteria for the termination of futile medical treatment, ethical controversies surrounding the provision of basic medical care and the problem of therapeutic obstinacy, we must take stock of the relevant terminology.

\section{Problems with definitions}

There are great number of expressions attached to medical interventions that fall into the category of inadequate treatment, and almost as many definitions of the latter. Nonetheless, all definitions take into account professional expertise, available means and prospects of recovery. What they differ in is the prominence they give to any of these factors and the philosophical and ethical context in which they operate when employed in the assessment of the patient's concrete medical state.

\subsection{Futile therapy}

The first group of expressions under our survey focuses on one of the most important objectives of medical interventions, i.e. efficiency. It includes

Cf. U. Benzenhöfer, Euthanasie und Sterbehilfe in Geschichte und Gegenwart, München, Verlag C. H. Beck, 1999, p. 37. 
pronouncements like futile therapy, therapeutic futility ${ }^{2}$, contraindicated treatment or pointless treatment ${ }^{3}$. They imply the evaluation of the concrete medical intervention in terms of its capacity for achieving intended good, weighed against its potential for inflicting harm. The practice of evaluating potential effects of medical interventions has a long history. Traditional distinction between ordinary and extraordinary forms of medical treatment - reaching back to the times of Pope Pius XII - though still in use, could not keep pace with the rapid development of medicine in recent decades and had to be supplemented with the distinction between proportional and disproportional ones.

The estimation of medical reasons behind intended procedures, though indispensable for a promising prescription, seems insufficient. It needs to be appended with the holistic evaluation of the well-being of the patient, done by his physician(s) and himself. A confrontation between opposite conclusions, based on subjective sets of values of involved parties, may be sometimes inevitable. Tom L. Beauchamp and James F. Childress say that: "This situation of competing conception and ambiguity suggests that we should generally avoid the term futility in favour of more precise language"

\subsection{Obstinate therapy}

The second group of expressions contain terms like therapeutic obstinacy, aggressive medical treatment ${ }^{6}$, overzealous treatment ${ }^{7}$ and therapeutic overzealousness. They indicate the maximisation of efforts and the use of full array of available medical means, regardless of their healing potential. The whole attention is on the physician, to the detriment of the patient's actual state and needs. Such overzealousness is ethically reprehensible and drained of empathy.

Therapeutic overzealousness and therapeutic obstinacy may owe their strength to the mistaken notion that the physician has the obligation to initiate a medical intervention and continue it no matter what. It may be fuelled by

2 In contrast to the above-mentioned expressions, the idea of futility makes a very rare appearance in the documents of the Catholic Church.

3 T. L. Beauchamp, J. F. Childress, Principles of Biomedical Ethics, 7th ed., New York, Oxford University Press, 2013, p. 169-170.

4 T. L. Beauchamp, J. F. Childress, Principles of Biomedical Ethics, p. 170.

5 Concluding Document, in: J. de Dios Vial Correa, E. Sgreccia (ed.), The Dignity of the Dying Person, Città del Vaticano 2000, p. 25.

6 John Paul II., Evangelium vitae 65.

7 Catechism of the Catholic Church, 2278. 
the fear of falling victim to accusations of failing in his duties and breaching the medical ethos if he chooses otherwise. At other times it can be caused by the physician's desire to sustain his patient's hope in recovery, to make the patient believe that his situation cannot be so desperate if they continue his treatment. Such attitudes are harmful to both physicians and patients. Physician must see and care for the whole human person, not only this or that part of his biological organism that needs attention. He must accept the truth that man is a vulnerable and finite creature. He cannot treat the death of his patient as his personal failure, but as the end of the last stage of his patient's life. When he is not able to impede it any longer, he should accept it. One of the essential tasks of the physician is to recognise the time when continuing treatment yields only additional and unnecessary suffering to his patient, with no prospect of recovery. When this moment arrives, his professional and ethical call to fight for the life and health of his patient as best as he can ought to give way to the compassionate accompaniment and alleviation of patient's pain and despair in the face of the approaching death.

\subsection{Exhausting therapy}

The third and the last group of expressions describe the effects of the therapeutic procedures that are particularly exhausting, exasperating ${ }^{8}$, or burdensome. Patient discomfort and pain must be measured against the desired outcomes. In many cases, for instance in terminal illness, the prescribed therapies and procedures, though extremely burdensome and exhausting, are necessary. In other cases, however, they are clearly not.

\section{Criteria for the termination of treatment}

Among the criteria that have to be met in order to make treatment decisions, including withholding or withdrawing treatment, are the following: the objective assessment of the efficacy of the medical intervention; due proportion between the means employed and the end pursued; subjective attitude to the medical intervention on the part of the physician and the patient.

Address of John Paul II to the World Organization of Gastro-Enterology, 23 March 2002, 2, in: http://w2.vatican.va/content/john-paul-ii/en/speeches/2002/march/documents/hf_jpii_spe_20020323_congr-gastroenterologia.html (30.06.2015). 


\subsection{Efficacy and proportionality of medical interventions}

The most important elements in the above mentioned definitions are the principles of efficacy and proportionality. Efficacy is the ability of an intervention to produce the desired, beneficial and clinically measurable effect. The crucial factor here is: what can be reasonably expected? Only a fully qualified physician is entitled to make such judgement. The decision-making process would be compromised if the principle of efficacy were not accompanied by the principle of proportionality, which seeks to determine the quantitative relation between the proposed means and the reasonably expected outcomes. Proportionality judgement should be grounded not only on the objective, clinical condition of the patient, but on the entire state of his affairs. What should be taken into account is not just the medical efficacy, but - as Maurizio Calipari puts it - global efficacy, which seeks “(...) the attainment of salutary effects that prove to be really significant for the life of the patient, according to his personal assessment, in the complex context of his existence and based on the axiological scale he has adopted"'.

In order to establish whether a planned intervention is proportional or disproportional to the expected results, the following factors should be considered: availability; technical set-up; the accuracy of the prognosis; potential risks; costs; and availability of alternative treatment ${ }^{10}$. The distinction between ordinary and extraordinary means should take into account the following: the effort required to obtain the proposed means; alleviation of pain; financial and other burdens to the patient and his family; anxiety; expected outcomes; and the patient's opinion on the risk involved, based on his own hierarchy of values ${ }^{11}$.

Calipari maintains that the application of means that are both proportional and ordinary is, in principle, morally obligatory. If they are proportional, but extraordinary, their application is morally optional, conditional on concrete circumstances. In the latter case, other factors must be considered too, for instance the patient's moral obligations towards other people and God. The application of means that are ordinary but disproportional is, in principle,

9 In E. Sgreccia, Personalist Bioethics. Foundations and Applications, Philadelphia NCBC 2012, p. 685. Cf. M. Calipari. The principle of Ethical Adequacy in the Use of Means of Preserving Life: Between Therapeutic Excess and Abandonment of the Patient, in: Alongside the Incurably Sick and Dying Person: Ethical and Practical Apsects, E. Scgreccia, J. Laffitte (ed.), Libreria Editrice Vaticana, Vatican City 1999, s. p. 165.

10 M. Calipari, The Principle of Ethical Adequacy, p. 162-167.

11 M. Calipari, The principle of Ethical Adequacy, p. 167-171. 
forbidden; unless the patient needs more time to fulfil some other, grave moral obligations he may have. The application of means that are both disproportional and extraordinary should never be allowed ${ }^{12}$.

Accurate assessment of efficacy and proportionality of a medical intervention can be extremely difficult. In early 2015, a two-year-old Polish boy in the severe hypothermic state, with his body temperature at the unbelievable low level of $12^{\circ} \mathrm{C}$, was admitted to the children's hospital in Kraków, Poland. Professor Skalski, a heart surgeon at the hospital, said: "In every practical sense, it was a corpse. When you see a patient whose entire nervous system is apparently shut down, with no neurological reflexes of any kind, no blood circulation and no spontaneous respiration, you have a full right to pronounce him dead. In such cases, it would be a near profanation if you proceeded with the resuscitation. But in this particular case, this little child still had a chance to survive"13. And he did! Dr Skalski added that the key reasons for his decision to apply resuscitation were his professional knowledge on hypothermia and the assessment of the patient's chances of survival. Thanks to the dedication, professionalism and sustained efforts of the rehabilitation team in the hospital, the boy was brought back from deep hypothermia and restored to health.

\subsection{Approaching death}

Therapeutic obstinacy has a tendency to manifest itself in especially acute forms in the final stages of terminal illness. Problems surrounding such situations are obvious for all to see. The accuracy of the prognosis in any given case may be - and often is - challenged. Definitions of death currently in use are problematic. Criteria for determining the moment of death are riddled with problems ${ }^{14}$. For the lack of space it must suffice for our present purpose to say that dying and death is a process rather than a single, identifiable event. Having said that, however, it would be unreasonable to summarily dismiss the

12 M. Calipari, The principle of Ethical Adequacy, p. 172-175. See also E. Sgreccia, Personalist Bioethics, p. 686; B. Chyrowicz, Bioetyka-anatomia sporu, Kraków, Znak 2015, p. 317-318: "When the forgoing of treatment is dictated neither by futility, nor disproportionality, it is nothing else but a passive euthanasia".

${ }_{13}$ For more on prof. Skalski's motives for proceeding with the treatment of the boy, see J. Skalski, J. Bątkiewicz-Brożek, Mam odwagę mówić o cudzie [I am not afraid to talk about the miracle], Kraków, Znak 2015, p. $208 \mathrm{ff}$.

14 Cf. N. Feinendegen, G. Höver (Ed.), Der Hirntod - Ein "zweites Fenster" auf den Tod des Menschen? Zum Neuansatz in der Debatte um das neurologische Kriterium durch den US-Bioethikrat, Königshausen \& Neumann, Würzburg 2013. 
professional capabilities of physicians to assert the certainty of the diagnosis and make realistic prognosis of improvement or deterioration, sufficient for a well-informed and considered decision on any given course of action.

Euthanasia is a deliberate medical intervention, undertaken with the express purpose of ending a life ${ }^{15}$. The alternative is not, however, keeping the person alive at whatever cost and by whatever means. Arriving at the accurate assessment of the proportionality of the medical means employed seems somehow easier in the situation of impending death. The reason for it is that it is being done in a different therapeutic context. Intensive care in such cases would have been severely limited, or terminated altogether, and conventional medical treatment replaced by the palliative care. The word palliative comes from late Medieval Latin word paliatus (cloaked). It refers to the holistic care for people with serious illness, which includes compassionate and loving accompaniment. In palliative care, the efficacy of medical interventions recedes into the background, and gives way to the concern for the general well-being of the patient. According to G. Virt, palliative care absorbs the medical knowledge and capacities, physical, mental and pastoral care, social work, physiotherapy, ergotherapy and - if needed - other fields of human knowledge ${ }^{16}$.

Therapeutic obstinacy may show itself in other circumstances, too. In the context of the comprehensive assessment of the rationale behind any given therapy, every futile therapy is obstinate. But not every obstinate therapy is necessarily futile. To illustrate this point, let us consider a therapy that may produce the desired, clinically measurable therapeutic effect, for instance, chemotherapy. Its beneficial effects might be real, but short-lived, paid for with great suffering of the patient ${ }^{17}$. Should the healthcare providers continue the treatment if the previous chemotherapy cycles were very painful and have not so far combatted the illness?

Decision-making processes in such circumstances are very hard indeed. Sooner or later, their participants must face the so-called quality-of-life issue. The term may be understood in two different ways. Usually, it is taken to mean that the patient does not suffer excessive or unnecessary physical pain and is

15 A short summary of catholic moral teaching on euthanasia cf. E. Sgreccia, Personalist Bioethics, p. 679-683.

16 See G. Virt, Leben bis zum Ende. Zur Ethik des Sterbens und des Todes, Innsbruck-Wien, Tyrolia 1998, p. 42.

17 B. Chyrowicz, Bioetyka. Anatomia sporu, Kraków, Znak 2015, p. 313. 
able to integrate his treatment into his life, without undue disturbance of his other daily activities and interests. Another way of evaluating the quality of life is concerned primarily with the anthropological context of man, and unilaterally concentrated on the autonomy of the individual person. This understanding of the term refers to the subjective boundaries, indicating the absence of the rationale for the continuation of one's life.

The concept of the quality of life always implies the assessment of its value. For those who confess the absolute sanctity of human life, it will never hit the zero value (not to mention the negative value, as some advocates of euthanasia propose). Where life as such has no separate, distinct value, but only an instrumental one, the obligation of its protection depends on whether the patient himself considers it worth protecting. The concept of the quality of life comes here to the foreground and becomes the primary ethical consideration when it comes to making a life-and-death decision at the end of one's life ${ }^{18}$.

It would be difficult to accept the simple, instrumental assessment of human life in the context of the personalistic ethics. In order to avoid a possible misunderstanding, it is important to stress that the conviction about the fundamental value of life does not have to be connected to vitalism. Keeping the patient alive, whether young or old, cannot be regarded as the end in itself. It cannot be the only factor in favour of or against a possible medical intervention in a given situation. Life must be protected, true. But not as an abstract, an idea or a concept, but always as concrete life belonging to concrete human being. The assessment of proportionality of medical intervention takes into account the general well-being of patient, not just its efficacy.

\subsection{Costs}

Nonmedical factors, such as financial costs of medical interventions, must also be taken into account when making the assessments of their proportionality. Consideration of cost as the most important ethical criterion for the initiation or withdrawal of therapy is characteristic to the utilitarian ethical concepts. This is not so in the personalistic concepts of man. Respect for human life makes it impossible to think about it in terms of gains and losses. The issue of costs is taken into account, too, but only as one of the many elements in the ethical assessment of medical interventions. When the available financial

18 Cf. E. Schockenhoff, Ethik des Lebens. Grundlagen und neue Herausforderungen, FreiburgBasel-Wien, Herder 2009, p. 536. 
and technical means are scarce, the necessity of considering the cost can be greater. Needless to say, a lot depends on the entire local healthcare system. If the cost involved is so high that it can ruin the patient's family, or severely restrict other patients' access to healthcare, whereas the expected beneficial outcome is slight, then the rationale for going ahead with the planned therapy is no longer valid. In such situations refraining from it is morally acceptable ${ }^{19}$.

\section{Disagreements over the provision of basic medical care}

The above-mentioned distinctions influence the extent of the provision of basic medical care, i.e. medical activities concerning the palliative care. Whereas medical interventions aim at combatting the illness and abnormal behaviour of the organism, basic medical care is limited to the provision of the optimal available means necessary to sustain life. It includes provision of food and fluids, lessening the discomfort, sustaining stable body temperature, personal hygiene, etc. It is often the same as, or similar to, the care of infants.

The most controversial issues are those that surround the use of life support systems, especially mechanical ventilators, used in the respiratory failure (sometimes colloquially called "respirators") and feeding tubes for artificial nutrition and hydration (ANH). What usually sparks off a major dispute is not whether to turn the system on or not, but when to turn it off. Participants engage each other with very tough questions: Can both these procedures be considered as therapeutic? What if they turn out disproportional and extraordinary? Can they be then aborted, in accordance with the principle that every medical intervention that is not obligatory may be terminated $?^{20}$ Or, do they rather belong to the category of basic medical care? If so, should they be regarded as always proportional and obligatory?

Let us examine the arguments for and against the use of mechanical ventilators first. Some ethicists argue that it can be withdrawn if the patient has no chance to recover spontaneous breathing, even if doing so can cause his death. They maintain that the mechanical ventilator is there to relieve patient's

19 Cf. P. Aszyk, Granice leczenia. Etyczny problem odstapienia od interwencji medycznych, Warszawa, Rhetos 2006, p. 150-155.

20 "The criteria that carry enough weight for the termination of treatment are, from the ethical point of view, equally valid for the gradual withdrawal of treatment or, if this proves impossible, for the definitive end of treatment”. E. Schockenhoff, Ethik des Lebens, p. 383. 
problems with breathing, not to replace his respiratory system for good. When you remove the ventilator, you don't cause death, they say. You only remove the artificial obstacle to death, which was coming anyway ${ }^{21}$.

Other ethicists insist that the stabilisation of the organism, brought about by the ventilator, creates a wholly new ethical situation, in which the two procedures, switching the ventilator on or off, are not the same. They stress the fact that the direct, immediate result of the withdrawal of artificial ventilation is cutting off the supply of the oxygen, its rapid depletion in the organism, and imminent death. A physician who undertakes such procedure puts himself into a very grave ethical conflict ${ }^{22}$.

The provision of artificial nutrition and hydration is a little bit different. Regular supply of nutrients and fluids is necessary for life. Unlike artificial ventilation, artificial nutrition and hydration is neither technically complicated, nor particularly painful or costly. It is relatively easy to reach a consensus on the natural provision of nutrition and hydration. For as long as the patient is able to ingest food and fluids, it is the positive duty of medical personnel, or family members, to provide it. This obligation ceases when the intake of nutrients and fluids fails to achieve its natural goal and is not absorbed by the organism, or results in additional suffering and discomfort. This usually occurs when death is imminent. It is a well-known fact that many dying persons do not manifest hunger or thirst. It would be difficult to proclaim that it is morally obligatory to make them eat and drink anyway.

The greatest controversies surround the problem of the provision of artificial nutrition and hydration to patients who are not terminally ill, for example, the persistent vegetative state (PVS) patients. Clinicians disagree on the likelihood of such patients regaining consciousness. Some maintain that it is highly improbable. Others cite examples of patients regaining cognitive functions even after remaining in the vegetative state for many years. In recent years, in the children's clinic "Budzik" in Warsaw (in free translation: The Wake-up Clinic), established several years ago, more than a dozen PVS children regained their consciousness. In each case the PVS lasted for less than a year. In general, the longer a person remains in the persistent vegetative state, the lesser is the likelihood of him ever regaining consciousness.

21 E. Schockenhoff, Ethik des Lebens, p. 391.

22 For more on this particular issue see E. Schockenhoff, Ethik des Lebens, p. 392-395. 
When then, if ever, does the obligation to feed the permanently unconscious cease? The question was brought to public attention with full force, very recently, by two cases of PVS patients: Terri Shiavo in USA and Eluana Englaro in Italy. Both women had their feeding tubes removed, and died shortly afterwards. Some considered it the termination of the obstinate therapy, because both patients had irreversibly lost their capacity for communication with the surrounding, which meant that they would never be able to lead their individual existence again. Others charged that what was done to these women was nothing short of passive euthanasia. When artificial nutrition and hydration do not cause additional suffering to a PVS patient and is easily tolerated by his organism, arguments that call it aggressive and disproportional are difficult to accept. Whatever the opinion on these cases, they certainly should make us aware that there is a very thin line between letting die and making dead, between the termination of obstinate therapy and passive euthanasia ${ }^{23}$.

\section{Additional ethical problems concerning therapeutic obstinacy}

Therapeutic obstinacy and proportionality of medical interventions give rise to a number of other ethical controversies, which deserve at least a cursory treatment here.

\subsection{On the question of truth at the sickbed}

How much truth can the patient endure? Not much, according to traditional, paternalistic approach in medicine. His capacity to tolerate bad news and comprehend what needs to be done to cure him is small, it was believed. Granted, usually a physician would conceal truth in good faith, for fear that it could hurt his patient. Well, truth sometimes hurts..., but deceit hurts even more. Nowadays, patient must be fully informed about the proposed therapy and agree to it. It is called: the informed consent.

23 Concerning the artificial feeding and watering of PVS patients cf. B. Chyrowicz, Biotyka. Anatomia sporu, p. 323-326; E. F. Diamond, A Catholic Guide To Medical Ethics. Catholic Principles in Clinical Practice, The Palos Park, Linacre Institut 2001, p. 126-130; W. J. Eijk, Shortening life through suspension or omission of life prolonging medical treatment, in: W. J. Eijk et al. (Ed.), Manual of Catholich Medical Ethics. Responsible Healthcare from a Cathilic Perspective, Ballarat, Conor Court Publishing 2010, p. 575-579; E. Schockenhoff, Ethik des Lebens, p. 395-399. 
But what about informed refusal? Should the patient be fully informed about his real state and the proposed withdrawal of the therapy, and agree to it, too? Critics of familiarising the patient with the whole truth about his diagnosis and prognosis argue that the most important thing for the patient, at every stage of his illness, is hope. He must never be deprived of it. Suppression of truth can actually help the patient because it keeps his hope alive. Anyway, many patients subconsciously do not even want to be confronted with the whole seriousness of their situation. Lastly, there is always an element of uncertainty of the diagnosis and the accuracy of the prognosis ${ }^{24}$.

None of these arguments carry enough weight to convince the advocates of telling the patient the whole truth. They argue that the assumption that the patient can know only good news cannot hold at certain stages of illness. Giving only evasive answers to patient's queries, or leaving him in the dark, often results in patient's seriously diminished confidence in his doctor and ultimately produces the opposite effect to the one intended. More often than not, truth revealed at the right time only confirms what the patient already knows or suspects. It may help him to reconstruct his life around his illness and give a new meaning to it.

Truth is the basis of any meaningful human communication. Concealing or misrepresenting the truth destroys trust and compromises further communication. The relationship between physicians and patients is one of the most delicate social relations. Society rightly expects that physicians display a high level of transparency and personal integrity. They should not lie to patients about their health, especially if the latter demand and expect reliable information. Of course, it does not mean an automatic, full disclosure, but rather what is relevant at any given time and circumstance. Telling truth at the sickbed is like administering medicine: it should be given in appropriate, healthy doses. Especially when the patient enters the terminal phase of illness. For the Christian patient, timely provided truth about his state can help him put his affairs in order and prepare himself to meet his Creator.

\subsection{Advance Decision}

In the western English speaking world, the term "Advance Decision" means a statement explaining what medical treatment the individual would not want in

24 E. Schockenhoff, Zur Lüge Verdammt? Politik, Medien, Medizin, Justiz, Wissenschaft und die Ethik der Wahrheit, Herder, Freiburg-Basel-Wien 2000, p. 491-503. 
the future, should that individual lack capacity to make such a decision in the future. Usually, it is a written document, which the individual signs either at any stage of his life, not necessarily during an illness, or on admission to hospital. It is also sometimes called the "Living Will" or "Do Not Resuscitate". In the German speaking world it is called "Patiententestament" or, more precisely, "Petientenverfügung".

Many people are getting a little bit apprehensive about the technological progress in medicine. They are afraid that if something really bad happens to them, the full force of all that medical technology will come on them. They simply do not want to be plugged-in to all those dreadful machines. In such situations, the Advance Decision may be very helpful. It can be helpful to a physician, who may withhold the use of complex and usually very expensive equipment without fear of being sued by the patient's family for negligence, and for the family, as it relieves them from having to make difficult and painful decisions.

The advance decision/living will statement may be a source of difficult ethical problems. It can contain demands that may prove totally inadequate in the particular situation, or outright unethical. Medical interventions that the patient wishes to be withheld may turn out to be neither extraordinary, nor disproportionate. Even if valid, should the physician carry them out to the letter, or readjust them according to the patient's concrete situation?

A research on the matter, conducted in 2009 in Germany by professor Stephan Sahm, indicated that the healthy often expressed quite a different view on sickness and disability than the sick. The former usually assumed a very limited range of suffering and disabilities they would be willing or able to cope with. Many respondents who did experience serious illness or disability confessed that, after initial shock and periods of depression, they were much more eager to undergo a necessary therapy and come to terms with their impairment that they had thought it possible before. Only very few respondents claimed unchanged opinion before and after a health incident ${ }^{25}$.

The source of the greatest unease among physicians, patients and ethicists is the binding nature of the advance decision document, especially if it involves physician involvement in, for instance, an act of euthanasia. Of course, every person has a right to dignified death; but it does not mean that every person has a right to euthanasia. Even if the patient thinks that his life is not worth

25 S. Sahm, Medizinische Entscheidungen am Lebensende. Alternativen zur Patientenverfügung, "Forschung Frankfurt" 2 (2007), p. 49. 
living any more, he cannot demand that his physician immediately stops all ordinary and proportional therapy and puts him to death without further delay.

Eberhard Schockenhoff said: "As long as the highest aim of the medical intervention is the well-being of the patient as the whole person, and not only fulfilment of his will, the physician must not shift his responsibility onto the written will of the patient, especially that it does not have to be, necessarily and unconditionally, identical with his real decision in the concrete situation"26.

From the Christian point of view, the will of the patient is morally acceptable only if it does not negate the fundamental value of human life, does not advance opinion that life in a seriously and irreversibly impaired manner is not worth living, and does not demand of the physician immoral acts or withdrawal of treatment. A Christian living will would be more like a declaration of acceptance of death. It may contain a wish to discontinue a therapy that, to the best available medical knowledge, is not likely to bring desired results and may only prolong suffering. Ethically acceptable content of such a document, as well as sufficient and adequate knowledge of the signing party, is of paramount importance.

\subsection{Conscience clause}

Conscience clause is a legislative provision that permits a physician to refuse to provide certain care related services for reasons of religion or conscience. For the purpose of this paper, we shall limit our inquiry to the right of the physician to refuse to perform or assist at euthanasia.

The idea of conscientious objection and conscience clause cannot be discussed in isolation from patient autonomy. Its many critics maintain that the right of a physician to act upon conscientious objection and refuse certain medical interventions directly violates patient autonomy. They argue that he is there to provide his patient with all available and legal services and his conscience has nothing to do with his job whatsoever. They may seem right; but they are not. Doctors are not there to fulfil patients' personal preferences or wishes. They too have the right to defend their autonomy and personal and professional integrity. Acting on the fundamental respect for human life, they can and should refuse provision of medical services that are justified by arbitrary evaluations of the quality or value of their patient's life, for instance in euthanasia ${ }^{27}$.

26 E. Schockenhoff, Ethik des Lebens, p. 383.

$27 \mathrm{Cf}$. L. Gormallz, Personal and social responsibility in the context of the defense of human life: the question of cooperation in evil, in: E. Sgreccia, J. Laffitte, Christian conscience in support 
Physician and patient may have different sets of values, convictions and beliefs. Sometimes, this difference may be a source of considerable tensions between one and the other. A physician may find it difficult to balance his duty to protect the life and health of his patient on the one hand, and to respect his right to self-determination on the other. A patient may feel being forced to accept what is against his conscience, but fear that his own demands and expectations may compromise his doctor's moral integrity.

Freedom of thought, conscience and religion are some of the most important affirmations of our times. Every human person has the right to act according to dictates of his conscience, and no one should be compelled to act against it. Physician may invoke the conscience clause in matters concerning fundamental human dignity. He may appeal to religion when it affects the basic ethical standards of the medical profession, like the life-and-death decisions. The fundamental duty of respect for human life is, of course, independent of his world view, but his religious convictions, or lack thereof, may enhance or diminish it. Growing dependence of medicine on economy and politics may produce further moral conflicts and trouble individual and collective conscience. Various ideologies are becoming ever more vocal in disseminating their views on what is ethical for healthcare providers and what is not ${ }^{28}$.

On 7 October 2010, the Council of Europe Parliamentary Assembly adopted Resolution 1763, confirming the right of physicians to conscientious objection. During a debate before the vote, there was a strong pressure to restrict the application of the conscience clause to the private sphere of the medical professionals and exclude from it hospitals and other health care institutions. Eventually, the Resolution 1763 stressed that: "No person, hospital or institution shall be coerced, held liable or discriminated against in any manner because of a refusal to perform, accommodate, assist or submit to an abortion, the performance of a human miscarriage, or euthanasia or any act which could cause the death of a human foetus or embryo, for any reason" 29 .

of the right to life, Citta del Vaticano, Libreria Editrice Vaticana 2008, p. 102-105.

28 For more on various aspects of conscience-based objection in health care see P. Stanisz, J. Pawlikowski, M. Ordon (ed.), Sprzeciw sumienia w praktyce medycznej-aspekty etyczne i prawne [Ethical and legal issues concerning conscience-based objection in health care], Lublin, KUL 2014.

$29 \mathrm{http} / / /$ assembly.coe.int/nw/xml/XRef/X2H-Xref-ViewPDF.asp?FileID=17909\&lang=en (30.06.2015). 


\section{Bibliography}

Aszyk P., Granice leczenia. Etyczny problem odstapienia od interwencji medycznych, Warszawa, Rhetos 2006.

Beauchamp T. L., Childress J. F., Principles of Biomedical Ethics, 7th ed., New York, Oxford University Press 2013.

Benzenhöfer U., Euthanasie und Sterbehilfe in Geschichte und Gegenwart, München, Verlag C. H. Beck 1999.

Calipari M., The principle of Ethical Adequacy in the Use of Means of Preserving Life: Between Therapeutic Excess and Abandonment of the Patient, in: Alongside the Incurably Sick and Dying Person: Ethical and Practical Apsects, E. Scgreccia, J. Laffitte (ed.), Libreria Editrice Vaticana, Vatican City 1999, p. 158-177.

Chyrowicz B., Bioetyka - anatomia sporu, Kraków, Znak 2015.

Catechism of the Catholic Church.

Council of Europe, Resolution 1763 (2010). The right to conscientious objection in lawful medical care, in: http://assembly.coe.int/nw/xml/XRef/X2H-Xref-ViewPDF. asp?FileID=17909\&lang=en (30.06.2015).

Concluding Document of the Fifth Assembly of the Pontifical Academy for Life, in: J. de Dios Vial Correa, E. Sgreccia (eds.), The Dignity of the Dying Person, Città del Vaticano, 2000, p. 25-28.

Diamond E. F., A Catholic Guide To Medical Ethics. Catholic Principles in Clinical Practice, The Palos Park, Linacre Institut 2001.

Eijk W. J., Shortening life through suspension or omission of life prolonging medical treatment, in: W. J. Eijk et al. (Ed.), Manual of Catholich Medical Ethics. Responsible Healthcare from a Cathilic Perspective, Ballarat, Conor Court Publishing, 2010, p. 561-582.

Gormally L., Personal and social responsibility in the context oft he defense of human life: the question of cooperation in evil, in: E. Sgreccia, J. Laffitte, Christian Conscience in Support of the Right to Llife, Citta del Vaticano, Libreria Editrice Vaticana 2008, p. 92-111.

John Paul II, Evangelium Vitae, in: http://w2.vatican.va/content/john-paul-ii/en/encyclicals/ documents/hf_jp-ii_enc_25031995_evangelium-vitae.html (30.06.2015).

John Paul II, Address to the World Organization of Gastro-Enterology, 23 March 2002, 2, in: http://w2.vatican.va/content/john-paul-ii/en/speeches/2002/march/documents/hf_jpii_spe_20020323_congr-gastroenterologia.html (30.06.2015).

Feinendegen N., Höver G. (Eds.), Der Hirntod - Ein "zweites Fenster" auf den Tod des Menschen? Zum Neuansatz in der Debatte um das neurologische Kriterium durch den US-Bioethikrat, Königshausen \& Neumann, Würzburg 2013.

Sahm S., Medizinische Entscheidungen am Lebensende. Alternativen zur Patientenverfügung, "Forschung Frankfurt" 2 (2007), p. 48-52.

Schockenhoff E., Ethik des Lebens. Grundlagen und neue Herausforderungen, FreiburgBasel-Wien, Herder 2009.

Schockenhoff E., Zur Lüge Verdammt? Politik, Medien, Medizin, Justiz, Wissenschaft und die Ethik der Wahrheit, Herder, Freiburg-Basel-Wien 2000.

Sgreccia E., Personalist Bioethics. Foundations and Applications, Philadelphia NCBC 2012.

Skalski J., Bątkiewicz-Brożek J., Mam odwagę mówić o cudzie, Kraków, Znak 2015. 
Marian Machinek

Stanisz P., Pawlikowski J., Ordon M. (eds.), Sprzeciw sumienia w praktyce medycznej-aspekty etyczne i prawne, Lublin, KUL 2014.

Virt G., Leben bis zum Ende. Zur Ethik des Sterbens und des Todes, Innsbruck-Wien, Tyrolia 1998. 